\title{
Peranan Pembelajaran Sejarah dalam Penanaman Nilai Karakter Religius dan Nasionalisme di MA NW Toya Lombok Timur
}

\author{
Siti Harah \\ Universitas Hamzanwadi \\ sitiharah@gmail.com
}

\begin{abstract}
Abstrak
Penelitian ini bertujuan untuk mengetahui bentuk peranan pembelajaran sejarah dalam penanaman nilai karakter religius dan nasionalisme di MA NW Toya, mengetahui peranan pembelajaran sejarah dalam penanaman nilai karakter relgius dan nasionalisme di MA NW Toya, dan kendala-kendala yang dihadapi guru dalam pembelajaran sejarah dalam menanamkan nilai religius dan nasionalisme di MA NW Toya. Penelitian ini menggunakan metode deskriptif kualitatif. Pengumpulan data dilakukan melalui teknik observasi, wawancara, dan dokumentasi. Analisis data menggunakan reduksi data, penyajian data, dan penarikan kesimpulan. Hasil penelitian menunjukkan bahwa sikap religius dan nasionalisme di MA NW Toya dapat dikatakan sudah baik. Hal ini dapat dilihat dari program-program yang diterapkan sekolah yang dijadikan peraturan sekolah, dan semakin lama menjadi kebiasaan siswa untuk melakukannya. Sikap religius dan nasionalisme juga dapat dibentuk melalui pembelajaran sejarah, dimana guru mengkaitkan materi sejarah tertentu dengan nilai religius dan nasionalisme. Peranan pembelajaran sejarah dalam penanaman nilai religius dan nasionalisme dapat dilihat dari materi yang sudah disampaikan salah satunya materi masuknya Islam ke Indonesia. Guru juga menerapkan nilai religius dan nasionalisme pada materi lain yang sudah disesuaikan dengan materi tersebut. Kendala-kendala yang dihadapi guru ialah pada saat perencanaan, pelaksanaan, dan evalusi beserta waktu jam pelajaran sejarah. Dalam perencanaan kurangnya buku penunjang yang dapat menambah referensi materi sejarah. Dalam pelaksanaan kurangnya waktu dan karakter pribadi siswa yang berbeda-beda.
\end{abstract}

Kata Kunci: Pembelajaran Sejarah, Nilai, Religius, Nasionalisme

\begin{abstract}
This study aims to determine the form of the role of history learning in instilling religious character values and nationalism in MA NW Toya, knowing the role of history learning in inculcating religious character values and nationalism in MA NW Toya, and the obstacles faced by teachers in learning history in instilling values. religion and nationalism in MA NW Toya. This study used descriptive qualitative method. Data was collected through observation, interview, and documentation techniques. Data analysis uses data reduction, data presentation, and drawing conclusions. The results showed that religious attitudes and nationalism in MA NW Toya can be said to be good. This can be seen from the programs implemented by the school which are used as school regulations, and it is increasingly becoming a habit for students to do so. Religious attitudes and nationalism can also be formed through history learning, where the teacher relates certain historical materials to religious values and nationalism. The role of history learning in
\end{abstract}


inculcating religious values and nationalism can be seen from the material that has been delivered, one of which is the entry of Islam into Indonesia. The teacher also applies religious values and nationalism to other materials that have been adapted to these materials. The obstacles faced by teachers are during planning, implementation, and evaluation along with the time of history lesson hours. In planning the lack of supporting books that can add historical reference material. In the implementation of the lack of time and the personal character of students who are different.

Keywords: History Learning, Values, Religion, Nationalism

\section{Pendahuluan}

Pendidikan karakter menjadi isu utama pendidikan pada abad ke-21 ini. Selain menjadi bagian dari proses pembentukan akhlak anak bangsa, pendidikan karakter diharapkan mampu menjadi pondasi utama dalam mensukseskan Indonesia. Indonesia memerlukan sumber daya manusia dalam jumlah dan mutu yang memadai sebagai pendukung utama dalam pembangunan. Untuk memenuhi sumber daya tersebut, pendidikan memiliki peran yang sangat penting (Fathurrohman, dkk. 2013: 9). Ketika bangsa Indonesia bersepakat memproklamirkan kemerdekaan Indonesia pada tanggal 17 Agustus 1945, para bapak pendiri bangsa menyadari bahwa paling tidak ada tiga tantangan besar yang harus dihadapi. Pertama,adalah mendirikan negara yang bersatu dan berdaulat, kedua adalah membangun bangsa, dan ketiga adalah membangun karakter. Ketiga hal tersebut, secara jelas tampak dalam konsep negara bangsa dan pembangunan karakter bangsa.

Pada implementasinya kemudian upaya mendirikan negara relatif lebih cepat jika dibandingkan dengan upaya untuk membangun bangsa dan membangun karakter. Kedua hal terakhir itu terbukti harus diupayakan terus-menerus, tidak boleh putus di sepanjang sejarah kehidupan bangsa Indonesia. Bahkan Bung Karno menegaskan bahwa bangsa Indonesia ini harus dibangun dengan mendahulukan karakter, karena denmgan karakter inilah yang akan membuat bangsa Indonesia yang besar, maju dan jaya, serta bermartabat. Kalau karakter ini tidak dilakukan, maka bangsa Indonesia akan menjadi bangsa kuli.

Persoalan budayadan karakter bangsa saat ini menjadi sorotan tajam masyarakat. Sorotan itu mengenai berbagai aspek kehidupan, tertuang dalam berbagai tulisan di media cetak, wawancara, dialog, dan gelar wicara di media elektronik. Persoalan yang muncul di masyarakat seperti, korupsi, kekerasan, kejahatan seksual, perusakan, perkelahian 
massa, kehidupan ekonomi yang konsumtif, kehidupan politik yang tidak produktif, dan sebagainya menjadi topik pembahasan hangat di media massa (Messi \& Harapan, 2017)

Jalan keluar yang banyak dikemukakan untuk mengurangi masalah budaya dan karakter bangsa itu adalah pendidikan.Pendidikan dianggap sebagai alternatif yang bersifat preventif, karena pendidikan membangun generasi baru bangsa yang lebih baik.Sebagai alternatif yang bersifat preventif, pendidikan diharapkan dapat mengembangkan kualitas generasi muda bangsa dalam berbagai aspek yang dapat memperkecil dan mengurangi penyebab berbagai masalah budaya dan karakter bangsa. Memang diakui bahwa hasil dari pendidikan akan terlihat dampaknya dalam waktu yang tidak segera, tetapi memiliki daya tahan dan dampak yang kuat di masyarakat.

Hal ini sesuai dengan Undang-undang Nomor 20 Tahun 2003 tentang Sistem Pendidikan Nasional pada Pasal 3 menyebutkan bahwa pendidikan nasional berfungsi mengembangkan kemampuan dan membentuk karakter serta peradaban bangsa yang bermartabat dalam rangka mencerdaskan kehidupan bangsa, bertujuan untuk berkembangnya potensi peserta didik agar menjadi manusia yang beriman dan bertakwa kepada Tuhan Yang Maha Esa, berakhlak mulia, sehat, berilmu, cakap, kreatif, mandiri, dan menjadi warga negara yang demokratis serta bertanggung jawab. Dengan demikian jelas sekali bahwa fungsi dan tujuan pendidikan berkaitan dengan pembentukan karakter peserta didik. Sehingga mampu bersaing, beretika, bermoral, sopan santun, dan berinteraksi dengan masyarakat. Mengingat pentingnya pendidikan karakter dalam membangun sumber daya manusia yang kuat, maka penerapannya haruslah dilaksanakan dengan perencanaan yang matang (Kementerian Pendidikan Nasional, 2010).

Salah satu pendidikan yang dapat menerapkan pendidikan karakter adalah pendidikan sejarah. Dalam pendidikan sejarah terdapat tujuan yang secara tidak langsung dapat membentuk karakter peserta didik. Tujuan dari pendidikan sejarah diantaranya adalah mengembangkan kemampuan berpikir kronologis, kritis, dan kreatif, membangun kepedulian sosial, mengembangkan semangat kebangsaan, membangun kejujuran, kerja keras, dan tanggungjawab (Hasan, 2012). Pendidikan sejarah menjadi sesuatu yang sangat penting. Dimana proses pengembangan nilai-nilai yang menjadi landasan dari karakter itu menghendaki suatu proses yang berkelanjutan. Dalam mengembangkan pendidikan karakter bangsa,kesadaran akan siapa dirinya dan bangsanya adalah bagian yang teramat penting.Kesadaran tersebut dapat terbangun dengan baik melalui 
pendidikan sejarah yang memberikan pencerahan dan penjelasan mengenai siapa dirinya dan bangsanya di masa lalu yang menghasilkan dirinya dan bangsanya di masa kini (Rulianto, 2018).

Dalam pendidikan sejarah ada nilai-nilai yang dapat diwariskan dan ditanamkan, salah satunya adalah nilai religius dan nasionalisme. Dalam pendidikan sejarah ada beberapa materi yang dapat dipelajari dari nilai religius dan nasionalisme. Seperti pada materi proses masuknya agama Hindu dan Buddha, agama Islam, penyebaran agama Islam di Jawa yang dilakukan oleh Wali Songo, dan banyak ditemukan peninggalanpeninggalan agama baik dari agama Hindu dan Buddha maupun dari agama Islam. Seperti bangunan masjid, Pura, Vihara, makam para Wali Songo/Wali Sembilan, dan lain sebagainya. Materi pendidikan sejarah juga menanamkan nilai nasionalisme.Karena tujuan dari pendidikan sejarah salah satunya ialah untuk menanamkan sikap nasionalisme.Selain itu, pelajaran sejarah juga mengajarkan bagaimana meneladani perjuangan para pahlawan dalam usahamempertahankan kemerdekaan Indonesia dari penjajah, hidup toleran dengan adanya berbagai macam suku, agama, ras, etnik, dan adat istiadat yang ada di Indonesia.

Dalam menjalin kehidupan di dunia ini agama memiliki posisi dan peranan yang sangat penting. Agama dapat berfungsi sebagai faktor motivasi (pendorong untuk bertindak yang benar, baik, etis dan maslahat), profetik (menjadi risalah yang menunjukkan arah kehidupan), kritik ( menyuruh pada yang ma'ruf dan mencegah dari yang mungkar), kreatif (mengarahkan amal atau tindakan yang menghasilkan manfaat bagi diri sendiri dan orang lain), integratif (menyatukan elemen-elemen yang rusak dalam diri manusia dan masyarakat untuk menjadi lebih baik), sublimatif (membebaskan manusia dari belenggu kehidupan) (Agustian, 2001; Ahmadi dan Salim, (2004). Manusia yang tidak memiliki pandangan hidup, lebih-lebih yang bersumber agama, ibarat orang buta yang berjalan ditengah kegelapan dan keramian: tidak tau dari mana dia datang, mau apa di dunia, dan kemana tujuan hidup yang hakiki (Bakhruddin, 2019: 63-71).

Nilai religius yang kuat merupakan landasan bagi siswa untuk kelak menjadi orang yang dapat mengendalikan diri terhadap hal-hal yang negatif. Tanda yang paling tampak oleh seseorang yang beragama dengan baik adalah mengamalkan ajaran agama yang dianutnya dalam kehidupan sehari-hari. Inilah karakter yang sesungguhnya perlu dibangun bagi penganut agama misalnya keimanan seseorang didalam islam barulah 
dianggap sempurna bila meliputi tiga hal yaitu keyakinan dalam hati, diikrarkan secara lisan, dan diwujudkan dalam tindakan nyata. Bila hal ini dilakukan dengan baik, berarti pendidikan karakter telah berhasil dibangun dalam proses belajar mengajar yang dilakukan di sekolah.

Karakter religius ini sangat dibutuhkan oleh siswa dalam menghadapi perubahan zaman dan degradasi moral. Dalam hal ini siswa diharapkan mampu memiliki kepribadian dan berprilaku sesuai dengan ukuran baik dan buruk yang didasarkan pada ketentuan dan ketetapan agama. Oleh karena itu siswa harus dikembangkan karakternya agar benar-benar berkeyakinan, bersikap, berkata-kata dan berprilaku sesuai dengan agama yang dianutnya.Untuk mewujudkan harapan tersebut dibutuhkan pendidik atau guru yang bisa menadi suri tauladan bagi siswa. Sekolah wajib menginstruksikan pembelajaran yang mengubah perilaku siswa yang terkandung dalam pendidikan karakter yang benilai nasionalisme untuk menginternalisasi nilai-nilai kepada siswa maupun warga sekolah meliputi komponen pengetahuan, kesadaran, kemauan, dan tindakan untuk melaksanakan nilai-nilai tersebut baik terhadap Tuhan, diri sendiri, sesama lingkungan, maupun dalam hidup kebangsaan. Dasar pendidikan karakter perlu dikembangkan dalam dunia pendidikan adalah mencakup aspek-aspek yang tercermin dalam pendidikan karakter seperti, menggembangkan potensi peserta didik menjadi manusia yang beriman, bertaqwa kepada Tuhan Yang Maha Esa, berakhlak mulia, sehat, berilmu, cakap, kreatif,mandiri, dan menjadi warga negara yang demokratis sertabertanggung jawab (Undang-Undang Nomor 20 tahun 2003).

Penelitian dalam konteks pembelajaran sejarah berperan penting dalam pendidian karakter religius dan nasionalisme kebangsaan sudah banyak dilakukan oleh peneliti lainnya. Secara umum penelitian-penelitian tersebut menjelaskan tentang peran penting pembelajaran sejarah dalam menanamkan karakter religius dan nasionalis pada siswa di sekolah (Rulianto, 2018; Winarsih, 2017; Amelia, 2015; Ahmad, 2014; Nihayah \& Adi, 2014; Fimansyah \& Kumalasari, 2015; Hasan, 2012). Salah satu sekolah yang sudah berupaya untuk menanamkan nilai- nilai karakter terutama nilai karakter religius dan nasionalisme adalah MA NW Toya Lombok Timur. Alasan pemilihan sekolah ini karena nilai karakter religius sesuai dengan visi sekolah, yaitu, terwujudnya insan berprestasi dan berakhlak mulia berlandaskan iman dan takwa. Selain itu, karena peneliti merasa penelitian mengenai nilai karakter religius dirasa menarik yang disesuaikan dengan latar 
tempat penelitian. Untuk nasionalisme sendiri, karena tujuan dari pembelajaran sejarah salah satunya adalah agar siswa dapat memiliki sikap nasionalisme. Dimana sikap nasionalisme memiliki ciri toleransi, cinta tanah air, dan semangat kebangsaan. Adapun tujuan penelitian ini adalah untuk mendeskripsikan bentuk nilai religius dan nasionalisme di MA NW Toya, menjelaskan peranan pembelajaran sejarah dalam penanaman nilai karakter religius dan nasionalisme di MA NW Toya, dan mengetahui kendala yang dihadapi guru dalam penanaman nilai karakter religius dan nasionalisme pada pembelajaran sejarah di MA NW Toya.

\section{Metode Penelitian}

Penelitian ini menggunakan metode deskriptif-kualitatif (Sukardi, 2003: 157). Metodologi kualitatif merupakan sebuah prosedur penelitian yang menghasilkan data deskriptif dari objek atau subjek yang telah diamati (Sugiyono, 2009). Sumber data dalam penelitian didapatkan melalui observasi, wawancara, studi kepustakaan, dan dokumentasi. Teknik analisis data yang digunakan adalah teknik analisis model interaktif. Analisis model interaktif meliputi tiga kompenen penting, yakni reduksi data, penyajian data, dan penarikan kesimpulan.

\section{Pembahasan}

\section{Profil MA NW Toya Lombok Timur}

MA NW Toya berada di Desa Toya, Kecamatan Aikmel, Kabupaten Lombok Timur. Madrasah ini berdiri tahun 2000, dengan status akreditasi B, yang berorganisasi induk yaitu NW, yang memiliki luas $4000 \mathrm{~m}^{2}$, dan Luas bangunan 3x72 $\mathrm{m}^{2}$. MA NW Toya terletak di Jalan Pariwisata Nomor 16 Toya Aikmel Lotim. Sekolah MA NW Toya memiliki bangunan yang cukup baik, dan juga memiliki beberapa ruang kelas yaitu, memiliki 6 ruang kelas, dan 1 ruang sebagai kantor, dan beberapa ruangan lainnya. Sekolah MA NW Toya di warnai dengan cat warna hijau.Dari masing- masing ruangan ada yang rusak berat dan ada yang rusak ringan salah satunya ialah ruang toilet guru dan toilet siswa.Dari hal ini lah siswa berharap agar pihak sekolah segera memperbaiki toilet yang rusak agar bisa di manfaatkan dengan baik.Jumlah dari keseluruhan dari bangunan- bangunan MA NW Toya terdapat 15 ruangan yang memiliki 
kondisi ada yang baik dan ada yang rusak ringan ataupun berat (Profil MA NW Toya, 2019).

MA NW Toya didirikan pada tahun 2002 dalam bentuk bangunan berukuran persegi panjang, dan keseluruhan sekolah tersebut berbentuk hurup U. Dikelilingi oleh rumah penduduk atau berada di tengah-tengah rumah masyarakat Desa Toya. Keadaan sarana dan prasarana sekolah MA NW Toya memiliki begitu banyak fasilitas yang disediakan, akan tetapi ada yang memiliki kondisi yang baik dan juga ada yang rusak berat. Salah satunya adalah meja dan kursi siswa yang berjumlah 64 meja dan 64 kursi yang diantaranya 54 yang masih baik dan masih bisa dimanfaatkan untuk belajar dan 10 yang sudah rusak atau lapuk dan tidak bisa di gunakan lagi. Pihak sekolah mengupayakan untuk membuat meja dan kursi yang baru dan mewarnai meja dan kursi yang lama agar menjadi baru dan lebih nyaman untuk di pakai belajar begitu juga dengan fasilitas yang lainnya (Observasi, 10 Mei 2019).

Mengenai keadaan guru khususnya tentang pendidikan pendidik dan tenaga kependidikan dapat diketahui bahwa sekolah MA NW Toya saat ini mempunyai guru berjumlah 28 orang. Guru yang mengajar pada umumnya berpendidikan S1 dibidangnya ada 25 orang dan 3 orang berpendidikan S2.Dari segi fisik, semuanya baik, normal dan tidak ada yang cacat. Guru di MA NW Toya berasal dari berbagai desa akan tetapi lebih banyak dari Toya. Untuk mengetahui keadaan siswa di MA NW Toya bisa diketahui bahwa jumlah siswa di tahun pembelajaran 2018 yaitu berjumlah 109 siswa dari kelas XXII. Dimana kelas X berjumlah 39 siswa, kelas XI berjumlah 36 siswa, kelas XII berjumlah 34 siswa. Pada kelas XI-XII hanya satu jurusan yang ada yaitu jurusan IPS.

\section{Peran Pembelajaran Sejarah dalam Penanaman Nilai Karakter Religius dan Nasionalisme di MA NW Toya}

Penanaman nilai karakter religius dan nasionalisme dalam pembelajaran sejarah di MA NW Toya sudah dilaksanakan oleh guru sejarah dengan cara mengintegrasikan ke dalam proses pembelajaran. Pendidik tidak hanya menyampaikan nilai-nilai karakter religius dan nasionalisme pada siswa dalam bentuk pengetahuan saja,tetapi membiasakan untuk diterapkan dalam kebiasaan sehari-hari. 
Hasil penelitian menunjukkan bahwa guru sejarah sudah menerapkan atau menanamkan nilai karakter yang religius dan nasionalisme saat pembelajaran berlangsung.Materi yang digunakan oleh guru sejarah di MA NW Toya dari buku paket yang didapatkan dari pemerintah. Penyampaian materi diimbangi dengan metode yang digunakan untuk mengimplementasikan pembelajaran sejarah,dan metode yang digunakan ialah metode diskusi. Pembelajaran akan semakin menarik dengan metode yang menarik pula,kalau pembelajaran sudah menarik maka siswa pun akan lebih aktif mengikuti pembelajaran.

Sikap religius dan nasionalisme tidak mudah untuk dimiliki oleh semua warga negara, sikap religius, dan nasionalisme perlu dibentuk dan tidak bisa langsung berhasil ditanamkan untuk setiap orang. Akan tetapi jika di lihat dari hasil observasi di lapangan, siswa-siswi di MA NW Toya sudah memiliki jiwa religius dan nasionalisme pada diri mereka,hal ini dapat di buktikan dari sikap dan aktivitas siswa yang mencerminkan sikap religius dan nasionalisme. Seperti yang diungkapkan oleh informan dari guru sejarah di MA NW Toya bahwa:

Penanaman nilai karakter religius dan nasionalisme pada saat pembelajaran sangatlah penting, dan itu dimulai ketika sebelum masuk kelas siswa melakukan aktivitas pagi yaitu imtakpagi,menghafal alqur:an,sholat dhuha,dan itu termasuk menanamkan nilai religius pada siswa,dan tidak hanya itu ketika didalam kelas,sebelum memulai pembelajaran,siswa juga melakukan yaitu bernyanyi dengan lagu Indonesia raya,dan itu adalah salah satu cara agar siswa tetap mencintai tanah air kita yaitu tanah air Indonesia (Wawancara, Rusli, 11 Mei 2019).

Dalam membangun karakter, ada namanya relaksasi dimana relaksasi ini ialah beristirahat,bersantai,dan lainnya. Dalam kehidupan sehari-hari, pikiran seseorang sering kali didesak untuk menyelesaikan berbagai tugas yang datang silih berganti dan di saat yang bersamaan ia juga harus menghadapi berbagai masalah yang juga harus diselesaikan satu persatu. Kita perlu mengistirahatkan pikiran, kita perlu relaksasi sejenak dengan melakukan sholat, mendengar kembali kembali suara hati Ilahiah, dan menyambutnya dengan kejernihan pikiran sehingga kita akan menjadi peka kembali (Agustian, 2001).

Keterkaitan antara mental dan fisik yang dinyatakan dalam temuan baru tentang adanya hubungan anatomi antara otak dan tubuh, hubungan antara keadaan mental dengan kesehatan fisik, pusat-pusat emosi memainkan peranan penting. Orang-orang 
yang dengan baik mampu mengatasi rasa tertekan mereka, sering kali memiliki teknik pengelolaan stress yang siap digunakan kapanpun diperlukan, entah dilakukannya sambil mandi,sambil olahraga atau lewat latihan yoga, sementara saya memilih meditasi. Dengan menjalankan metode relaksasi semacam itu, tidak berarti bahwa kita tidak akan pernah merasa kesal atau tertekan lagi, namun latihan relaksasi yang kita kerjakan secara teratur agaknya dapat membantu mengurangi rasa lelah yang kita rasakan.

Contoh relaksasi sekaligus bukti ilmiah bahwa salah satu fungsi dari sholat lima waktu adalah untuk relaksasi yang sangat penting untuk menjaga kondisi emosi seseorang dari tekanan yang bisa mengakibatkan kebodohan dan intelektual dan menurunnya kesehatan jasmani. Fungsi relaksasi pada sholat akan memberikan ruang berpikir bagi perasaan intuitif, sekaligus menstabilkan kecerdasan emosi serta spiritual seseorang dan menjaga kefitrahan suara hati. Inilah metode pemeliharaan asset paling berharga yaitu hati dan intelektualitas manusia.Karena pentingnya sampai-sampai Allah SWT memerintahkan langsung kepada manusia untuk melaksanakan ibadah sholat tersebut melalui Rasulullah ketika beliau isra’ Mi'raj (Agustian, 2001).

Kegiatan awal atau pembukaan pembelajaran dimulai dengan berdoa, dan menyanyikan lagu kebangsaan. Guru selalu mengkondisikan kelas agar siswa benarbenar sudah siap untuk menerima pelajaran sejarah. Selanjutnya guru mengulang pelajaran yang sudah dipelajari sebelumnya dan memotivasi siswa dengan mengajukan pertanyaan sesuai materi sebelum pelajaran dimulai. Guru sejarah memanfaatkan proses belajar mengajar sejarah untuk mengembangkan nilai-nilai karakter religius dan nasionalisme siswa. Adapun model atau metode yang digunakan ialah metode ceramah dan diskusi .

Metode diskusi diharapkan dapat mengembangkan nilai kerja sama di antara para siswa atau peserta didik. Melalui diskusi mereka akan kompak mengerjakan tugas dan mencari jawaban atas tugas yang diberikan. Presentasi hasil dari tugas yang diberikan akan mampu mendorong rasa berani dalam diri siswa untuk berani berbicara didepan kelas atau di depan banyak orang. Terdapat beberapa metode yang bisa mengembangkan nilai karakter religius maupun nasionalisme yaitu ceramah, tanya jawab dan diskusi. Diskusi adalah salah satu metode yang tepat untuk mengembangkan nilai-nilai karakter tersebut. Kegiatan akhir yang menjadi penutup didalam pembelajaran yaitu guru melakukan refleksi materi yang sudah dipelajari pada kegiatan awal atau inti, menarik 
kesimpulan,dan memberikan penguatan kepada siswa serta dengan berdoa (Wawancara, Rusli, 11 Mei 2019).

Karakter religius dan nasionalisme siswa terbentuk dari program-program sekolah yang semakin lama menjadi kebiasaan siswa untuk dilakukan,sebagaimana yang diungkapkan oleh kepala sekolah MA NW Toya bahwa:

"penanaman nilai karakter religius dan nasionalisme pada siswa sangat perlu diterapkan karena sangat mendukung visi dan misi sekolah, dengan memprogramkan kegiatan-kegiatan dengan terlaksananya visi dan misi sekolah dan kebijakan yang lain yaitu jika siswa terlambat diberi hukuman dengan sholat tobat,istigfar $100 \mathrm{X}$, dan menghafal kosa kata bahasa arab dan bahas inggris (Wawancara, Izzudin, 13 Mei 2019).

Pembangunan karakter tidaklah cukup hanya dengan penetapan misi saja. Itu perlu dilanjutkan dengan proses yang terus-menerus sepanjang hidup melalui gerak sholat. Melalui sholat, seseorang akan dapat memvisualisasikan prinsip hidupnya yaitu keenam prinsip dalam pembangunan mental berdasarkan rukun Iman. Dengan menyediakan waktu beberapa menit sehari untuk sholat, ia memiliki kesempatan untuk membuat pikirannya lebih rileks dan setelah itu ia dapat berpikir jernih tentang dirinya serta menemukan pemecahan-pemecahan masalahnya. Berkaitan dengan hal di atas, sebagaimana yang diungkapkan oleh Waka Kurikulum bahwa:

Dalam menanamkan nilai karakter religius dan nasionalisme, yang pertama dilakukan ialah guru menyiapkan perangkat yang berkarakter, pelaksanaannya pun akan kurang maksimal,kalau kita mengikuti perangkat yang sudah disiapkan disitu sudah tertera nilai sikap, agama, religiusnya,mereka harus mengikuti program yang sudah di rencanakan disekolah,misalnya untuk pagi hari mereka imtak,pembacaan alqur'an dilanjutkan dengan menghafal kemudian sebelum pulang mereka melaksanakan sholat dzhur berjamaah (Wawancara, Sulhan, 14 Mei 2019).

Solat juga memberikan kekuatan afirmasi yang dapat membantu seseorang untuk lebih menyelaraskan nilai-nilai positif keimanan dengan realitas kehidupan. Afirmasi atau penegasan memiliki lima dasar yaitu, pribadi, positif, masa kini, visual, dan emosi. Emosi menyulut kreatifitas, kolaborasi, inisiatif, dan transformasi sedangkan penalaran logis berfungsi, mengantisipasi dorongan-dorongan keliru, untuk kemudian menyeleraskannya dengan proses kehidupan dengan sentuhan manusiawi. Dalam Islam, hal-hal yang berhubungan dengan kecakapan emosi dan spritiual seperti konsistensi (istiqamah), kerendahan hati (tawadhu), berusaha dan berserah diri (tawakkal), ketulusan 
(keikhlasan), totalitas (kaffah), keseimbangan (tawazun), integritas dan penyempurnaan (ihsan) itu dinamakan Akhlakul Karimah (Agustian, 2001).

Konsep ini di madrasah selalu mengajarkan para siswanya untuk selalu memiliki akhlakul karimah yang baik bagi semua orang dan berguna bagi sesama. Pembelajaran sejarah juga memiliki nilia-nilai didalamnya yang bisa ditangkap disetiap pembelajaran salah satunya nilai religius dan nasionalisme yang menuntut kita untuk menjadi manusia yang jujur,sopan santun, cinta terhadap tanah air bangsa, menjaga tanah air dengan segenap jiwa dan raga. Sebagaimana yang diungkapakan oleh salah satu guru mata pelajaran biologi Herniawati bahwa setiap guru harus menanamkan nilai itu karena sekalipun sarana dan prasarana kita tidak lengkap tapi bagaimana cara seorang guru untuk bagaimana siswa kita itu memiliki nilai yang baik dari sebelumnya, banyak hal yang harus kita lakukan supaya siswa kita itu mendapat nilai karakter yang baik tentunya dengan cara pendampingan (Wawancara, 13 Mei 2019).

Dalam pembelajaran sejarah,perlu adanya pengunaan model pembelajaran yang sesuai dengan materi. Hal tersebut agar siswa tidak cepat merasa jenuh akan materi yang disampaikan. Tujuan dari pembelajaran tersebut juga akan tersampaikan dengan baik. Di MA NW Toya ini masih mengunakan kurikulum 2013 jadi mau gak mau harus menjadikan siswa lebih aktif agar kelas tidak membosankan. Hal ini diungkapkan oleh Jariyah yang juga baru-baru ini memegang mata pelajaran sejarah,bahwa:

Daya tarik peserta didik itu ke negara kita, kita tunjukkan mereka bagaimana flim waktu perang pada masa lampau, atau kita suruh melihat video-videonya jadi kadang mereka itu ada yang menangis termasuk flim-flim G30/S/PKI, jadi sebagian besar anak- anak itu menangis melihat kondisi pahlawan kita pada masa lampau, sehingga dari sanalah bangkit jiwa nasionalisme mereka (Wawancara, 2 Juni 2019.

Selain guru sejarah, guru-guru yang lain juga menerapkan nilai karakter religius dan nasionalisme pada siswa di setiap pembelajarannya, seperti yang diungkapkan oleh salah satu guru Aqidah Akhlak. Dalam setiap pembelajaran, saya selalu menyuruh siswa-siswi di dalam kelas untuk berdoa sebelum belajar,dan itu termasuk salah satu bentuk nilai karakter religius yang setiap harinya dilakukan,dan tidak hanya itu,sebelum masuk kelas juga semua siswa kumpul dan melakukan aktivitas pagi yaitu imtak,menghafal alqur'an (Wawancara, Masnah, 3 Juni 2019).

Dari semua hasil wawancara di atas dapat disimpulkan bahwa bentuk peran pembelajaran sejarah dalam penanaman nilai karakter religius dan nasionalisme yaitu, 
guru sejarah mengkaitkan materi yang disampaikan dengan nilai karakter religius dan nasionalisme tersebut,dan tidak hanya guru sejarah saja yang menanamkan nilai karakter religius dan nasionalisme tetapi guru-guru yang lain juga termasuk guru Aqidah Akhlak, PKN, serta didukung dengan program-program sekolah. Untuk mengantisipasi serta menyeimbangkan sisi emosional siswa, dibutuhkan pengalaman-pengalaman positif sebagai "penawar/penyelaras" yang dapat menetralkan kembali dampak lingkungan yang telah mempengaruhi hati serta pikiran siswa. Dengan melakukan sholat secara rutin, maka sesungguhnya kita menciptakan pengalaman batiniah sekaligus pengalaman fisik yang mendorong paradigma ke arah positif (Agustian, 2001).

Suatu kegiatan fisik akan lebih mudah diingat apabila dilakukan berulang-berulang, ketika secara fisik seseorang melakukan ruku atau sujud berkali-kali, maka kegiatan itu akan membekas pada ingatan. Kegiatan yang dilakukan secara berulang-ulang akan menciptakan kebiasaan dan kebiasaan rutin tersebut akan menghasilkan pengalaman yang berujung pada pembentukan nilai. Itulah sebabnya dibuat program-program sekolah yang menjadi kebiasaan setiap harinya untuk dilaksankan oleh semua siswa agar mereka menghasilkan pengalaman yang membentuk diri mereka menjadi manusia yang baik, pelajar yang memiliki etika dan penerus yang berguna bagi nusa dan bangsa. Salah satu program sekolah ialah sholat dhuha, sholat adalah salah satu mekanisme untuk menampung dorongan, seseorang akan memperoleh keseimbangan antara dorongan keinginan dan kenyataan lewat mekanisme solat, karena sholat menampung dorongan yang energy yang tinggi dari seseorang yang berjuang sebagai khalifah sebagai wakil Allah yang bertugas memakmurkan bumi.

Berdasarkan hasil wawancara, dan observasi, terungkap bahwa peranan pembelajaran sejarah dalam penanaman nilai karakter religius dan nasionalisme di MA NW Toya berjalan sangat efektif. Hal tersebut diindikasikan dari beberapa keterangan yang diungkapkan oleh narasumber yang mengemukakan bahwa peranan pembelajaran sejarah dalam menanamkan nilai karakter religius dan nasionalisme di MA NW Toya sangatlah penting,mengingat semua kegiatan atau program-program yang di susun berjalan sesuai harapan.

Penanaman nilai nasionalisme sikap siswa dilakukan melalui pembelajaran sejarah di aplikasikan siswa selalu mencontoh sikap-sikap siswa selalu mencontohkan sikapsikap pahlawan, seperti tidak kenal lelah untuk selalu berjuang dan selalu bertahan 
disetiap rintangan. Guru sejarah dalam pembelajaran selalu melakukan pendekatan kepada siswa agar selalu meninggalkan perbuatan yang dapat merusak moral dan menanamkan nilai-nilai nasionalisme dalam pembelajaran yang terkandung dalam pelajaran sejarah di setiap mengajar,seperti menceritakan kisah-kisah perjuangan para pahlawan agar siswa selalu mencontohkan sifat-sifat para pahlawan. Hal ini diperkuat dengan hasil wawancara bahwa cara yang dilakukan dengan memberi penjelasan kepada siswa untuk lebih bersikap baik dan menyisipkan nilai- nilai moral di setiap pembelajaran sejarah seperti, menceritakan kisah perjuangan para pahlawan dahulu (Wawancara, Rusli, 11 Mei 2019).

Pada setiap proses belajar mengajar selain menanamkan nilai-nilai nasionalisme pada siswa,guru sejarah juga memberikan nilai-nilai agama tujuannya agar siswa selalu mengingat kepada tuhan agar tidak melanggar norma-norma yang ada dan agar siswanya menjadi makhluk yang religius atau beragama. Kalau dengan cara menceritakan kisah perjuangan para pahlawan tidak bisa diterapkan pada siswa atau tidak berhasil, guru mencoba mencari jalan yang lain seperti, mengingatkan pada mereka pada sang pencipta agar tidak berbuat negatif (Wawancara, Rusli, 11 Mei 2019).

Dalam suatu pembelajaran dikelas sebenarnya sebagian besar guru bisa menyampaikan materi dengan jelas dan baik kepada peserta didik,karena memang pekerjaan guru adalah suatu profesi yang memang sudah dibekali kepada mahasiswa calon guru ketika mengenyam pendidikan di perguruan tinggi. Tugas guru disekolah bukan hanya sebagai pendidik yang bertugas menyampaikan materi tetapi juga sebagai pendidik yang bertugas mendidik moral peserta didik agar mempunyai sikap yang baik.

Saya menjadi guru dari tahun 2012-sekarang, dan saya mengajar mata pelajaran sejarah,bagi saya sejarah itu sangat penting diterapkan pada siswa karena itu adalah dasar apa yang pernah ada di Indonesia karena bangsa kita pernah pasang surut dan kita harus mengetahui asal bangsa Indonesia itu dari mana,kemudian Indonesia berkembang seperti apa,oleh karena itu mata pelajaran sejarah itu sangat penting agar apa yang pernah terjadi itu menjadi pelajaran kita untuk masa yang akan datang (Wawancara, Rusli, 11 Mei 2019).

Peranan pembelajaran sejarah sangatlah jelas penting dalam menanamkan nilai religius dan nasionalisme bagi peserta didik,dan tidak hanya itu pihak sekolah pun memberikan kebijakan-kebijakan yang mendukung agar apa yang di inginkan baik kepala sekolah maupun guru-guru lainnya tercapai atau berhasil. Hal ini dapat di perjelas dengan ungkapan pak kepala sekolah disaat diwawancarai mengenai kebijakan-kebijakan yang 
diberikan sekolah terhadap penanaman nilai karakter religius dan nasionalisme di MA NW Toya:

Di sekolah ini kita harus menanamkan nilai religius dan nasionalisme kepada semua murid yang ada disini karena sangat mendukung visi dan misi sekolah yaitu "terciptanya sumber daya manusia (SDM) yang islami berkualitas menuju insan yang muttaqin" dan alhamdulilah itu berhasil kita terapkan,contohnya mereka diperintah pagi datang,mereka berdoa,mengaji,menghafal alqur'an,sholat dhuha,sholat jamaah dan sebelum pulang mereka membaca doa pusaka,dan Nasionalisme itu terkait dengan kurikulum yang sudah diterapkan oleh pemerintah. Berbicara mengenai kebijakan,disini kebijakan yang saya berikan ialah memprogramkan kegiatan-kegiatan yang terkait dengan terlaksananya visi dan misi sekolah,dan bagi siswa yang terlambat di beri hukuman dengan istigfar $100 \mathrm{X}$,dan sholat thobat,menghafal kosa kata bahasa arab dan inggris 50 kata (Wawancara, Izzudin, 11 Mei 2019).

Nilai-nilai yang dikembangkan melalui pembelajaran sejarah di MA NW Toya disesuaikan dengan materi dan lingkungan yaitu:

1. Cinta tanah air,yang memiliki arti sebagai cara berpikir, bersikap, dan berbuat yang menunjukkan kesetiaan,kepedulian dan penghargaan terhadap bahasa, lingkungan sosial, budaya, ekonomi dan politik bangsa. Nilai ini terdapat pada materi penyebaran agama Islam di Indonesia. Sehingga siswa dapat menghargai jasa para tokoh penyebar agama Islam di Indonesia, dan mengaplikasikan dalam kehidupan sehari-hari. Jujur merupakan kesatuan antara ucapan dan prilaku,nilai jujur

2. Nilai kejujuran yang dikembangkan dalam diri siswa di MA NW Toya diharapkan dapat membuat para siswa menjadi pribadi yang lebih baik di masa yang akan datang.

3. Disiplin sebagai tindakan yang menunjukkan perilaku tertib dan patuh terhadap ketentuan dan peraturan yang sudah diterapkan termasuk datang pagi ke sekolah.

4. Bersahabat dengan sesama memperlihatkan rasa senang berbicara, bergaul, dan bekerja sama dengan yang lain.

Religius adalah sikap dan perilaku yang patuh dalam melaksanakan ajaran agama lain dan hidup rukun dengan pemeluk agama lain yaitu toleransi terhadap sesama. Di dalam pembelajaran, Ada proses ilmu pengetahuan dan peradaban manusia yang di mulai dengan kata "iqra" (bacalah). Proses ini pun tak luput dari dorongan suara hati untuk ingin selalu mengetahui berbagai hal. Itu adalah dorongan dari Allah Yang Maha Ilmu, dorongan suara hati untuk belajar, yang bersemayam dalam setiap jiwa manusia. Sebagaimana yang diungkapkan oleh Waka Kurikulum bahwa: 
Untuk nilai religius, dan menghadapi tantangan zaman yang saat ini sangat luarbiasa teknologi ini,jadi harus ada remnya,apapun yang dilakukan nanti pada saat mereka akan melanjutkan pendidikannya jadi harus ada remnya,remnya itu akan berfungsi untuk menghentikan ketika ada hal-hal negatif yang muncul baik itu dalam diri mereka maupun diluar diri mereka,itu fungsinya untuk religious (Wawancara, Sulhan, 14 Mei 2019).

Kemudian nasionalisme juga sangat penting dan sudah mulai ditinggalkan sekarang terkait contoh sederhana lagu-lagu nasional yang sudah banyak dilupakan padahal itu sangat penting. Padahal ketika kita mengingat sejarah, kita mengingat perjuangan pahlawan maka rasa nasionalisme itu akan muncul,ketika rasa nasionalisme itu muncul. Anak-anak akan merasa memiliki tanggung jawab untuk mengisi kemerdekaan dengan hal yang positif, karna apa yang mereka rasakan saat ini bukan gratis. Apa yang mereka nikmati sekarang bersumber dari nasionalisme para pahlawan. Dalam menanamkan nilai karakter yang religius dan nasionalisme kepada para siswa MA NW Toya, tidak hanya dengan belajar sejarah saja tetapi pelajaran yang lain juga termasuk pelajaran-pelajaran yang bernuansa agama seperti mata pelajaran Aqidah Akhlak, ke NW-an. Seperti dijelaskan salah satu guru yang memegang mata pelajaran ke-NW-an:

Nilaireligius dan nasionalisme itu harus ada didalam diri manusia,lebih-lebih sebagai seorang pendidik dan peserta didik yaitu guru dan murid,dan bagi saya semua mata pelajaran memiliki atau menanamkan nilai religi maupun nasionalnya karena semua bermanfaat bagi siswa,banyak belajar banyak juga wawasan yang didapatkan,dan itu harus diaplikasikan dipada kehidupan sehari- hari (Wawancara, Nurmala, 3 Juni 2019).

Dalam pembelajaran ada pelatihan prinsip pembelajaran salah satu contoh ialah setiap kali sholat, kita di wajibkan membaca dan menghayati surat Al-Fatihah, intisari dari Alqur'an Al-Karim. Isi Al- Fatihah ini secara garis besar adalah tentang pujian atas sifat-sifat mulia, prinsip member, visi, intergritas, aplikasi, penyempurnaan, evaluasi, dan prinsip ikhlas. Apabila kita hayati isinya, maka Al-Fatihah merupakan bimbingan total bagi pembangunan jiwa dan pikiran (Iman), pelaksanaan (Islam) dan penyempurnaan (Ihsan). Sebagaimana yang diungkapkan oleh salah satu guru:

Program yang menjadi peraturan sekolah kita disini yaitu selalu mendampingi siswa untuk mengerjakan sholat fardhu Dzuhur sebelum pulang, Karna kita ketahui bahwa sholat ialah tiang agama dan kewajiban kita sebagai seorang muslim muslimat, karenanya kita selalu mendampingi siswa karena yang kita khawatirkan kalau mereka tidak sholat sebelum pulang takutnya nanti mereka tidak langsung sholat sampai rumah, dan itu yang harus kita antisipasi, ketika mereka 
sudah mengerjakan sholat di sekolah kan mereka bisa istirahat pulangnya, dan jadinya mereka tidak melalaikan sholat karena sebelumnya sudah tepat waktu di sekolah (Wawancara, Herniawati, 3 Juni 2019).

Sholat merupakan sebuah doa dan doa merupakan sebuah visualisasi, jadi sholat yang dilakukan secara rutin dan berulang-ulang akan menciptakan gambar yang sangat kuat dalam jiwa serta pikiran seseorang. Seperti yang diungkapkan oleh salah satu guru yang lain bahwa program sekolah menjadi nilai religius dan nasionalisme untuk siswa, bukan hanya guru sejarah yang menerapkan nilai itu akan tetapi semua guru disini, kita disini membuat program yang dapat mengembangkan nilai karakter yang ada pada diri siswa (Wawancara, Tammimi, 3 Juni 2019).

Berdasarkan hasil wawancara di atas, betapa pentingnya menanamkan nilai karakter religius dan nasionalisme pada siswa baik dengan mempelajari pelajaran sejarah maupun yang lainnya,karena dengan nilai karakter yang religius dan nasionalisme akan membuat manusia menjadi lebih baik ke depannya. Dalam konteks pembelajaran sejarah hal ini tentu saja sangat diperlukan agar siswa semakin memiliki tingkat kesadaran sejarah yang baik.

\section{Kendala yang Dihadapi Guru dalam Penanaman Nilai Karakter Religius dan Nasionalisme di MA NW Toya}

Peran penting pembelajaran sejarah sebagai penanaman nilai karakter yang religius dan nasionalisme disebabkan oleh beberapa hal yaitu; 1) Banyaknya masalah moral yang merusak kepribadian siswa,beragam masalah seperti tawuran,kecurangan dalam ujian,sampai pergaulan bebas kini meraja lela; 2) Tantangan globalisasi menuntut penyikapan yang bijak yang tertuju pada kearifan; 3) Masyarakat oleh karenanya perlu penguatan bagi masyarakat untuk menyikapi perubahan global melalui sejarah; 4) Pengembangan karakter perlu membutuhkan praktik yang baik dan keteladanan dari nilai-nilai kepahlawanan yang terkandung dalam pelajaran sejarah (Hasan, 2012).

Namun demikian, penanaman nilai karakter religius dan nasionalisme dalam pembelajaran sejarah bukan tanpa kendala. Pengembangan materi pembelajaran sejarah yang memiliki keterkaitan dengan menanamkan nilai karakter religius dan nasionalisme tidak mudah untuk diterapkan. Kendala-kendala tersebut dari segi perencanaan, pelaksanaan, penilaian, dan perencanaan. Salah satu guru sejarah menjelaskan bahwa: 
Kita kekurangan ketersediaan buku penunjang lain yang dapat menambah materi selain dari buku pegangan sendiri. Dari segi pelaksanaan terdapat pada karakter siswa sendiri,karena siswa berasal dari kalangan berbeda,begitu juga dengan karakternya berbeda,ada yang baik dan kurang baik. Dari segi evaluasi atau penilaian,saya kurang hafal karakter masing-masing siswa sehingga saya sedikit sulit untuk memahami apakah penanaman nilai karakter religius dan nasionalisme sudah dapat membentuk karakter siswa". Kendala lain yang di hadapi guru sejarah ialah waktu atau jam pelajaran,sesuai dengan yang diungkapkan oleh pak rusli guru sejarah bahwa "kendala yang dihadapi ialah jam mata pelajaran di akhir atau di jam terakhir,dimana para siswa ada yang lelah,menggantuk,dan ada yang tidak memperhatikan.dan ini menjadi kendala bagi saya selama pembelajaran berlangsung (Wawancara, Rusli, 11 Mei 2019 ).

Dalam mendidik siswa itu tidak selamanya akan berjalan mulus dan lancar,ada kendala-kendala yang dihadapi oleh pendidik, apalagi sekarang berkembangnya globalisasi terutama dalam hal teknologi informasi yang menyebabkan siswa menjadi terlena dengan keasyikan. Hal ini menjadi kendala yang sangat menghambat proses menanamkan nilai karakter religius maupun nasionalisme pada siswa. Masalah ini terjadi karena guru maupun orang tua kadang kala tidak dapat membatasi arus informasi yang begitu keras untuk siswa. Siswa saat ini memiliki kesempatan yang luas dalam mengakses informasi yang beraneka ragam. Penjelasan salah satu guru:

Kendala-kendala yang dihadapi disekolah ini memang ada tetapi sedikit dan tidak terlalu banyak,dan kendala tersebut ada siswa yang terlambat mengikuti program imtak pagi,dan itu yang menjadi kendala saat ini ketika siswa masih ada yang terlambat ke sekolah,dank arena itulah sekolah membuat kebijakan-kebijakan bagi yang terlambat diberi hukuman dengan beristigfar $100 \mathrm{X}$, Sholat tobat,dan menghafal kosa kata bahasa arab dan inggris 50 kosa kata (Wawancara, Izzudin, 13 Mei 2019 ).

Kendala lain yang dihadapi oleh guru antara lain seperti disampaikan oleh Waka Kurikulum bahwa:

Tentu saja kendalanya banyak, yang pertama disiswa sendiri ialah jarak dari rumah dengan sekolah itu terlalu jauh, tentunya siswa yang kadang-kadang terlambat dan seperti yang di bilang tadi bahwa kita selalu memberikan masukan dan siswa sendiri akan menyesuaikan yang jauh rumahnya dari sekolah bakalan berusaha untuk pagian datang atau berangkat ke sekolah, yang kedua kaitannya dengan masyarakat,jadi kita berusaha siswa itu tidak kita berikan keluar akan tetapi karna kita atau lembaga kita ruang terbuka jadi agak sulit untuk mengantisipasi hal itu apalagi dilembaga tidak ada kopsis (koperasi siswa) sehingga para siswa keluar belanja,nah ketika mereka keluar itu tentunya mereka akan berinteraksi dengan luar dari segi sikap bahasa dan itu yang kita khawatirkan sebenarnya. Yang ketiga kecilnya anggaran yang ada dilembaga kadang-kadang tidak mencukupi (Wawancara, Sulhan, 13 Mei 2019). 
Tidak hanya Waka Kurikulum yang memiliki kendala, akan tetapi guru lainnya juga seperti dari guru biologi mengungkapkan bahwa:

Setiap proses pasti ada tantangannya, dan tantangan itu membuat kita lebih menjadi keras dalam menghadapi tantangan itu sendiri. kendalanya biasanya anak yang kurang masuk karna mungkin kurang motivasi dari orang tua atau factor yang lain dan kita disekolah tetap memperhatikan itu dan kita disini tetap menghimbau untuk siswa agar selalu tetap menjalankan prosesnya sebagai siswa (Wawancara, Herniwati, 13 Mei 2019).

Dari segi motode pembelajaran, guru dirasa perlu untuk meningkatkan kemampuan dan keterampilan dalam memanfaatkan berbagai metode yang menarik dan memotivasi siswa untuk lebih aktif belajar. Hal ini bertujuan agar siswa mampu mengembangkan kemampuan berpikir,sikap dan bertindak sekaligus. Dari sekian banyak kendala-kendala yang diungkapkan oleh informan di atas pastinya memiliki cara tersendiri untuk mengatasi kendala tersebut. Salah satu guru sejarah menjelaskan bahwa kendala jam terakhir, disitu hingga berusaha membuat suasana kelas menjadi bergairah baik dengan mengunakan motede permainan agar siswa yang menggantuk jadi bergairah lagi belajarnya, dan mencari buku penunjang lain untuk menambah wawasan siswa selain dari buku pegangan yang sudah dimiliki (Wawancara, Rusli, 13 Mei 2019).

Dengan memperbaiki sistem jam pembelajaran, guru sejarah juga berusaha untuk mengoptimalkan dalam menyampaikan materi agar siswa tidak merasa jenuh dan bosan, sehingga dengan memakai metode permainan mengurangi rasa lelah dan ngantuk siswa. Selain guru sejarah, Waka Kurikulum juga menegaskan bahwa:

Disaat keluar main atau jam istirahat, sekolah mengadakan atau memiliki satpam, jadinya setiap ada siswa yang ingin keluar selain meminta izin kepada guru, siswa juga harus minta izin kepada satpam dan memberitahukan kemana tujuan siswa atau kemana siswa akan pergi, jadi seperti itu cara mengatasi salah satu kendala yang sudah saya paparkan tadi (Wawancara, Sulhan, 13 Mei 2019).

Selain Waka Kurikulum, kepala sekolah juga menyampaikan bahwa:

Upaya yang kita lakukan ialah dengan cara memberi hukuman kepada yang sering terlambat mengikuti kegiatan pagi agar mereka tidak mengulanginya lagi dan bisa mengikuti kegiatan tersebut. upaya yang lainnya tentunya kita pihak sekolah lebih mengawasi siswa dan membimbing mereka untuk menjadi lebih baik lagi dari sebelumnya. upaya yang kita lakukan ialah dengan cara memberi hukuman kepada yang sering terlambat mengikuti kegiatan pagi agar mereka tidak mengulanginya lagi dan bisa mengikuti kegiatan tersebut. Upaya yang lainnya tentunya kita pihak sekolah lebih mengawasi siswa dan membimbing mereka untuk menjadi lebih baik lagi dari sebelumnya (Wawancara, Sulhan, 14 Mei 2019). 
Dari beberapa ungkapan diatas bahwa kendala-kendala yang dihadapi baik guru sejarah, kepala sekolah, waka kurikulum, dan guru lainnya memiliki cara dan upaya agar apa yang menjadi kendala saat ini bisa berkurang dan membuat siswa menjadi sosok pribadi atau siswa yang lebih baik dan bisa mewujudkan visi sekolah yang sudah dibuat dan dijalankan. Segala sesuatu tidak terlepas dari rintangan dan cobaan, selalu ada likuliku yang dihadapu, karena semua proses tidak akan pernah berjalan mulus. Semoga apa yang menjadi kendala guru saat ini dalam menanamkan nilai religius dan nasionalisme pada siswa bisa menjadi motivasi agar selalu semangat dalam menerpakan nilai tersebut.

\section{Kesimpulan}

Karakter religius dan nasionalisme terbentuk dari program-program yang semakin lama menjadi kebiasaan siswa untuk di lakukan. Kebiasaan inilah yang semakin lama secara tidak langsung dapat membentuk sikap religius dan nasionalisme siswa. Karena program-program sekolah tersebut dijadikan peraturan-peraturan yang harus ditaati oleh semua siswa. Peranan pembelajaran sejarah dalam menanamkan nilai karakter religius dan nasionalisme di MA NW Toya dapat dilihat ketika guru menyampaikan materi-materi sejarah,dari materi tersebut guru mengkaitkan nilai religius dan nasionalisme yang dapat dipelajari oleh siswa. Peranan pembelajaran dalam menanamkan nilai karakter sangat penting,karena didalamnya pelajaran sejarah mengembangkan cinta tanah air yang memiliki arti sebagai cara berpikir, bersikap, dan berbuat yang menunjukkan kesetiaan, kepedulian dan penghargaan terhadap bahasa, lingkungan sosial, budaya, ekonomi, dan politik bangsa. Jujur merupakan kesatuan antara ucapan dan prilaku,nilai jujur. nilai kejujuran yang dikembangkan dalam diri siswa di MA NW Toya diharapkan dapat membuat para siswa menjadi pribadi yang lebih baik di masa yang akan datang. Disiplin sebagai tindakan yang menunjukkan perilaku tertib dan patuh terhadap ketentuan dan peraturan yang sudah diterapkan termasuk datang pagi ke sekolah. Bersahabat dengan sesama memperlihatkan rasa senang berbicara, bergaul, dan bekerja sama dengan yang lain. Kendala dari segi pelaksanaan ialah berasal dari karakter siswa itu sendiri. Siswa berasal dari keluarga yang berbeda, maka berbeda pula karakter siswa yang satu dengan yang lain. 


\section{Daftar Rujukan}

Agustian, Ary Ginanjar. (2001). Rahasia Sukses Membangun Kecerdasan Emosi dan Spiritual ESQ: Emotional Spiritual Quotient 165,1 Ihsan 6 Rukun Iman dan 5 Rukun Islam, Jakarta: Arga.

Ahmad, T. A. (2014). Kendala Guru dalam Internalisasi Nilai Karakter pada Pembelajaran Sejarah. Khazanah Pendidikan, 7(1).

Ahmadi, Abu dan Noor Salim, (2004). Dasar-Dasar Pendidikan Agama Islam, Jakarta: PT. Bumi Aksara.

Amelia, C. (2015). Peranan Pembelajaran Sejarah Dalam Penanaman Sikap Nasionalisme Siswa Kelas XI IPS SMA Negeri 1 Pecangaan. Indonesian Journal of History Education, 3(2).

Bakhruddin, Mukhammad. (2019), Pembentukan Karakter Religius dalam Pendidikan Islam di Era Revolusi Industri 4.0 Perspektif Generasi Millenial. Prosiding Seminar Nasional Agama Islam. Malang: Universitas Negeri Malang.

Fathurrohman, Pupuh dkk. (2013). Pengembangan Pendidikan Karakter. Bandung: PT Refika Aditama.

Fimansyah, W., \& Kumalasari, D. (2015). Penanaman Nilai-Nilai Nasionalisme Melalui Pembelajaran Sejarah di SMA Kebangsaan Yogyakarta. ISTORIA: Jurnal Pendidikan dan Sejarah, 11(1).

Hasan, S. H. (2012). Pendidikan Sejarah Untuk Memperkuat Pendidikan Karakter. Paramita: Historical Studies Journal, 22(1).

Hasil Observasi, 10 Mei 2019.

Kementerian Pendidikan Nasional. (2010). Pengembangan Pendidikan Budaya dan Karakter Bangsa. Bahan Pelatihan Penguatan Metodologi Pembelajaran Berdasarkan Nilai-Nilai Budaya untuk Membentuk Daya Saing dan Karakter Bangsa. Jakarta: Badan Penelitian dan Pengembangan Pusat Kurikulum.

Messi, M., \& Harapan, E. (2017). Menanamkan Nilai Nilai Kejujuran dalam Kegiatan Madrasah Berasrama (Boarding School). JMKSP (Jurnal Manajemen, Kepemimpinan, dan Supervisi Pendidikan), 2(2), 278-289.

Nihayah, S., \& Adi, A. S. (2014). Penanaman Nasionalisme Pada Siswa Madrasah Aliyah Negeri 1 Bojonegoro di Tengah Arus Globalisasi. Kajian Moral dan Kewarganegaraan, 3(2), 829-845.

Profil MA NW Toya Tahun 2019.

Rulianto, R. (2018). Pendidikan Sejarah Sebagai Penguat Pendidikan Karakter. Jurnal Ilmiah Ilmu Sosial, 4(2), 127-134.

Sugiyono, (2009), Metode Penelitian Kuantitatif Kualitatif dan $R \& D$, Bandung: Alfabeta.

Sukardi, (2005). Metodologi Penelitian Pendidikan: Kompetensi dan Praktiknya, Jakarta: Bumi Aksara.

Wawancara, Herniawati, 3 Juni 2019. 
Jurnal Humanitas

Vol. 6 No. 1, Desember 2019, hal. 55-75

Wawancara, Herniawati, 13 Mei 2019.

Wawancara, Herniawati, 2 Juni 2019.

Wawancara, Izzudin, 11 Mei 2019.

Wawancara, Izzudin, 13 Mei 2019.

Wawancara, Masnah, 3 Juni 2019.

Wawancara, Nurmala, 3 Juni 2019.

Wawancara, Rusli, 11 Mei 2019.

Wawancara, Rusli, 13 Mei 2019.

Wawancara, Sulhan, 13 Mei 2019.

Wawancara, Sulhan, 14 Mei 2019.

Wawancara, Tammimi, 3 Juni 2019.

Winarsih, I. (2017). Peranan Pembelajaran Sejarah dalam Penanaman Nilai Karakter Religius dan Nasionalisme di MAN Temanggung Tahun Ajaran 2016/2017. Skripsi. Semarang: Universitas Negeri Semarang. 